\title{
TWO AMPHIBIANS, ONE OF THEM NEW, FROM THE CARBONIFEROUS OF ILLINOIS.
}

\author{
By Roy L. Moodie, \\ of the University of Kansas, Lawrence
}

The Lacoe collection in the United States National Museum contains examples of two interesting amphibians, one of them a new species, from the Mazon Creek shales. A new labyrinthodont from Kansas has recently been described by the writer from the same collection. ${ }^{1}$ The two forms discussed in the present paper are representatives of the salamander-like Branchiosauria and the reptile-like Microsauria. They are members of the families Branchiosauridæ and Amphibamidæ.

Some years ago Mr. David White told the writer of an interesting salamander in the collection of Mr. Lacoe and it was with very great interest that the writer received the specimen which, with the others, was sent through the courtesy of Mr. C. W. Gilmore, to whom I express my hearty thanks.

The little salamander-like fossil is a member of the species Eumicrerpeton parvum Moodie, which had been founded, before the specimen was received, on material from Yale University. The name and a discussion of the alimentary canal were published last spring. ${ }^{2}$ The additional specimen from the National Museum serves to substantiate the genus and species, Eumicrerpeton parvum, and shows more clearly characters which are distinct from Micrerpeton, the genus to which the present form is most nearly related. The National Museum specimen (No. 4400, U.S.N.M.), like those from Yale, shows almost perfectly the entire length of the alimentary canal (fig. 1). The specimen is almost as perfectly preserved as was that of Micrerpeton caudatum Moodie.

When the nodule containing the fossil was received the tail was embedded in matrix, but by careful use of the hammer and chisel it was possible to lay bare the whole tail, the tip of which ends on the

1 Proc. U. S. Nat. Mus., vol. 39, 1911, p. 489.

2 Amer. Nat., vol. 44, June, 1910, pp. 367-375.

Proceedings U. S. National Museum, Vol. 40-No. 1828. 
very edge of the nodule. This was at once perceived to be precisely similar to that of the previously studied examples from Yale. The skull structure, the intermediate position of the pineal foramen, the epiotic notch, and the shape of the skull are so exactly similar to those of the Yale specimens that the form is unhesitatingly referred to the same species.

Most interestingly, too, the present specimen has the alimentary

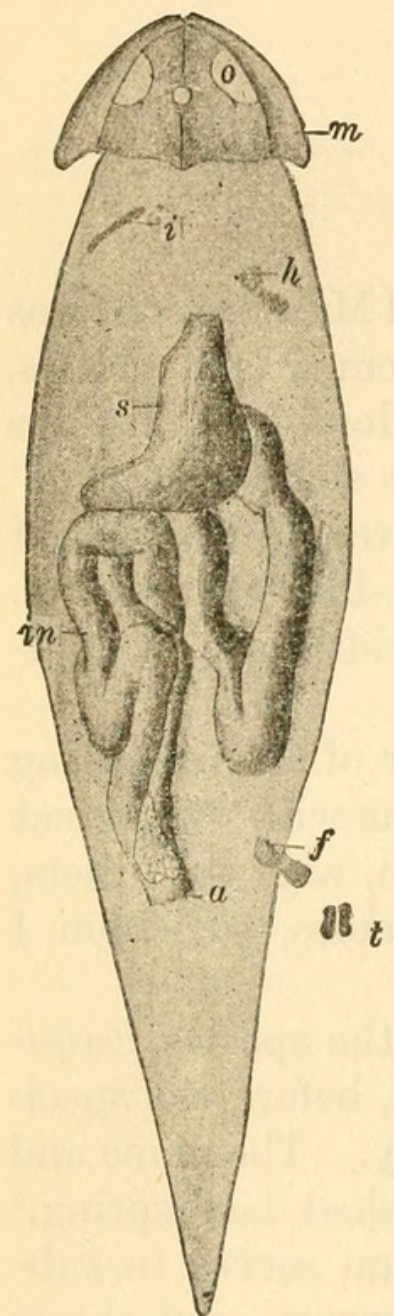

Fig. 1.-A DRAWING OF THE SPECIMEN OF EUMICRERPETON PARVUM Moodie (CAt. No. 4400, U.S. N.M.). $\quad a=$ ANUS; $f=$ FEMUR; $h=$ HUMERUS; $i=$ INTERCLAVICLE; $i n=$ INTESTINE; $m=$ MANDIBLE; $\quad o=$ ORBIT; $\quad s=$ STOMACH; $t=$ TIBIA AND FIBULA. $\times 2$. canal almost as prefectly preserved as in the other two specimens, so that the three specimens of this species now known all show the alimentary canals. The present specimen is, however, much more developed than the other two if we may judge from the relative sizes and the proportions of the various parts of the body. There is not the slightest trace of branchiæ in any of the specimens. The matrix does not preserve the skeletal elements as well as does the hard rock from Saxony in which Doctor Credner found such excellently preserved branchiæ.

The National Museum specimen is nearly half as long again as the smallest of the Yale specimens, and the skull is proportionately longer and wider. There is preserved an impression of the anterior edge of both clavicles as has been described for the Yale specimens. No other portion of the pectoral girdle is preserved. The right humerus is imperfectly preserved, as is also the right femur and tibia; other than these the fossil is merely an impression.

The skull is so nearly like what has been described for the Yale specimens that additional description is unnecessary. ${ }^{1}$ The pineal foramen is quite large and lies on a line which cuts the orbits into equal longitudinal parts. The interorbital space is about equal to the long diameter of the orbit, as in the Yale specimens. Traces of sclerotic plates are observed in the left orbit, but they are quite imperfect.

The alimentary canal is unlike that described for the Yale specimens ${ }^{2}$ in that the intestine is longer and much more convoluted. It lies in five longitudinal folds and ends in an enlarged cloaca near which are the impressions of two glands which may be the posterior ends of the oviducts, as has been suggested for the Yale specimens, but it is rather peculiar that all three specimens should 
to distinguish the one from the other. Parts of the plants have been converted into or destroyed by galena and kaolin, as have also parts of the bones, so that the task has been doubly difficult. There can be no doubt, however, that the observations recorded below are correct. The position of the arm in relation to the pectoral girdle and the position of the girdle in relation to the skull impression first called attention to the possible presence of a fossil amphibian.

There is little to be said about the skull. It is merely an impression in the nodule. It is triangular in form, with the snout an acute angle. The angle is, however, exaggerated by the compression to which the fossil has been subjected. The right side of the skull lies
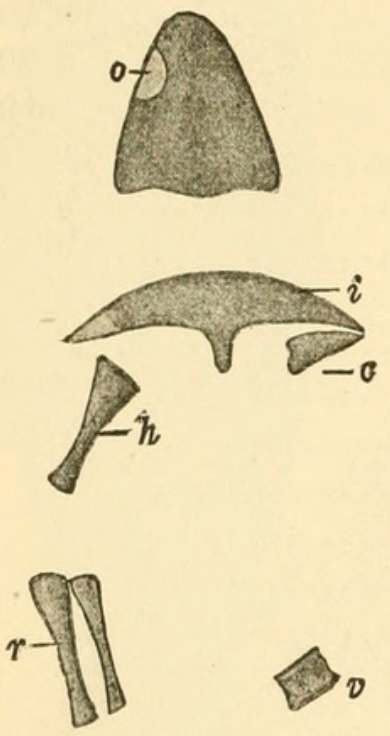

FIG. 2.-DRAWING OF THE SPECIMEN OF AMPHIBAMUS THORACATUS Moodie (CAT. No. 4306, U.S. N.M.). $\quad c=$ ClavICLE; $h=$ HUMERUS; $i=$ INTERCLAVICLE; $\quad 0=$ ORBIT; $r=$ RADIUS (ULNA?); $v=$ VERTEBRA. $\times 1$. over a portion of some plant. The animal is preserved on its back, so that this gives a good opportunity for a study of the pectoral girdle, which is partially preserved. The interclavicle is very large, and from this the species has been given its name (thoracatus=armed with a breastplate). The interclavicle is an exaggerated "T," with the stem very short. The anterior margin is curved and ends in a rather sharp, elongate point. The posterior spine is quite short and sharp pointed, having a length of only four millimeters. The element recalls, in a measure, the same element of Branchiosaurus, although it is much more expanded anteriorly and has a shorter spine. In these respects it resembles more nearly a reptilian interclavicle. The element is quite smooth.

The clavicle is of the simple triangular form so characteristic of the Microsauria. It is somewhat displaced backward, and its inner margin is slightly obscured.

The humerus is elongate, apparently cylindrical, and with expanded ends. It resembles very closely the humerus of Amphibamus grandiceps, although its proportions are much greater than in that species. Its length is almost equal to the length of the skull, while in A. grandiceps the length of the humerus is only one-half that of the skull.

The radius (ulna?) resembles in its general proportions those of the humerus. It is a more slender, lighter bone. The impression of the other bone of the forearm is obscured.

A portion of a single vertebral centrum is preserved. It is from the posterior end of the dorsal series. It is, apparently; amphicœlous. Its height is about one-half greater than its length. The neural spine is obscured. 
Measurements of the type of Amphibamus thoracatus Moodie (Cat. No. 4306, U.S.N.M.).

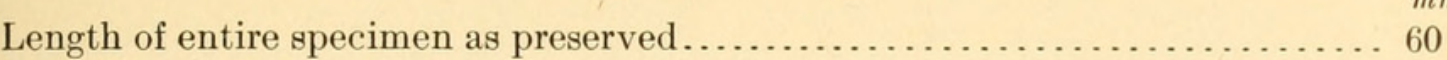

Length of skull impression........................................ 18

Greatest width of same.......................... 15.5

Long diameter of right orbit............................... 4

Transverse diameter of same............................... 3

Transverse width of the interclavicle.......................... 14

Long diameter of same.............................. 7

Long diameter of clavicle.................................. 9

Greatest transverse diameter of same........................... 3

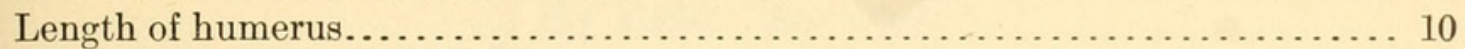

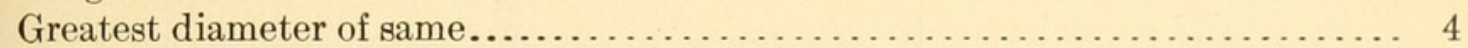

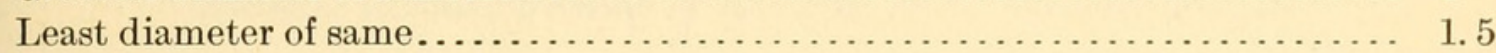

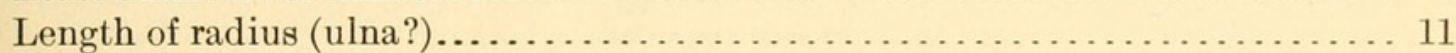

Length of vertebral centrum................................... 2

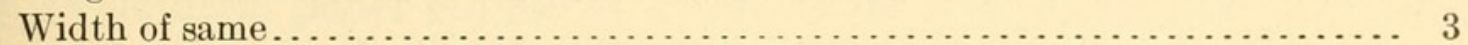

$80796^{\circ}$-Proc.N.M.vol.40-11-28 


\section{$2 \mathrm{BHL}$ Biodiversity Heritage Library}

Moodie, Roy Lee. 1911. "Two amphibians, one of them new, from the Carboniferous of Illinois." Proceedings of the United States National Museum 40(1828), 429-433. https://doi.org/10.5479/si.00963801.40-1828.429.

View This Item Online: $\underline{\text { https://www.biodiversitylibrary.org/item/53820 }}$

DOI: https://doi.org/10.5479/si.00963801.40-1828.429

Permalink: https://www.biodiversitylibrary.org/partpdf/53285

\section{Holding Institution}

Smithsonian Libraries

\section{Sponsored by}

Smithsonian

\section{Copyright \& Reuse}

Copyright Status: Public domain. The BHL considers that this work is no longer under copyright protection.

This document was created from content at the Biodiversity Heritage Library, the world's largest open access digital library for biodiversity literature and archives. Visit BHL at https://www.biodiversitylibrary.org. 